\title{
Bone resorption in parathyroid carcinoma
}

\author{
Negar Naderi, Michael T McCurdy, Robert M Reed
}

Pulmonary and Critical Care Medicine, University of Maryland School of Medicine, Baltimore, Maryland, USA

\section{Correspondence to} Dr Robert Michael Reed, rreed@medicine.umaryland.edu

Accepted 21 April 2014

\section{(a) CrossMark}

To cite: Naderi $\mathrm{N}$ McCurdy MT, Reed RM. BMJ Case Rep Published online: [please include Day Month Year] doi:10.1136/bcr-2013203396

\section{DESCRIPTION}

A man in his 30s with a history of end-stage renal disease (ESRD) and metastatic parathyroid carcinoma presented to the hospital with severe shortness of breath, hypercalcaemia and diffuse bone pain. Chest radiograph (figure 1A) demonstrated profound demineralisation, and the distal phalanges appeared abnormal (figure 1B) due to bony resorption characteristic of severe hyperparathyroidism. Parathyroid carcinomas are an exceeding rare cause of hyperparathyroidism. It is important to

\section{Learning points}

- Parathyroid carcinomas are a very rare cause of hyperparathyroidism. The HRPT2 gene mutations have been implicated in sporadic and familial variations of the disease. ${ }^{1}$

- Currently, the only successful treatment for this disease is surgical intervention with en bloc resection of the tumour; there are no effective chemotherapeutic options. ${ }^{2}$

- For those who are not surgical candidates, control of hypercalcaemia with calcimimetic agents and bisphosphonates is the mainstay of treatment. ${ }^{2}$ distinguish between benign parathyroid adenomas and parathyroid malignancies, since the latter carries a very high mortality and the only successful treatment is surgical resection. ${ }^{1}{ }^{2}$ As with this patient, those with parathyroid carcinomas, unlike their counterparts with benign adenomas, tend to be younger, have ESRD or some degree of renal insufficiency, have severe hypercalcaemia $(>15 \mathrm{mg}$ / $\mathrm{dL})$ and present with intense symptoms. ${ }^{2}$ Radiological findings such as osteitis fibrosa cystica (figure 1A) are far more common in parathyroid carcinomas (44-91\%) compared with benign parathyroid adenomas $(5 \%)$ due to the degree of parathyroid hormone elevation and bone resorption seen in the former. ${ }^{2}$

Funding RMR is funded in part by the Flight Attendant Medical Research Institute (FAMRI).

Competing interests None.

Patient consent None.

Provenance and peer review Not commissioned; externally peer reviewed.

\section{REFERENCES}

1 Cetani F, Pardi E, Borsari S, et al. Genetic analyses of the HRPT2 gene in primary hyperparathyroidism: germline and somatic mutations in familial and sporadic parathyroid tumors. I Clin Endocrinol Metab 2004;89:5583.

2 Shane E. Clinical review 122: parathyroid carcinoma. J Clin Endocrinol Metab 2001;86:485. 


\section{Images in...}

Copyright 2014 BMJ Publishing Group. All rights reserved. For permission to reuse any of this content visit http://group.bmj.com/group/rights-licensing/permissions.

BMJ Case Report Fellows may re-use this article for personal use and teaching without any further permission.

Become a Fellow of BMJ Case Reports today and you can:

- Submit as many cases as you like

- Enjoy fast sympathetic peer review and rapid publication of accepted articles

- Access all the published articles

- Re-use any of the published material for personal use and teaching without further permission

For information on Institutional Fellowships contact consortiasales@bmjgroup.com

Visit casereports.bmj.com for more articles like this and to become a Fellow 